\title{
5. ISOTOPE GEOCHEMISTRY OF LEG 115 BASALTS AND INFERENCES ON THE HISTORY OF THE RÉUNION MANTLE PLUME1
}

\author{
William M. White, ${ }^{2}$ Michael M. Cheatham, ${ }^{2}$ and Robert A. Duncan ${ }^{3}$
}

\begin{abstract}
Strontium, neodymium, and lead isotope ratios are reported for $13 \mathrm{Leg} 115$ basalts as well as 3 basalts from Texaco drill hole SM-1 on the Mascarene Plateau. The ${ }^{87} \mathrm{Sr} /{ }^{86} \mathrm{Sr}$ ratios and $\epsilon_{\mathrm{Nd}}$ range from 0.70330 to 0.70439 and 5.5 to 7.4, respectively, although ${ }^{87} \mathrm{Sr} /{ }^{86} \mathrm{Sr}$ ratios higher than 0.70383 are found only in $\mathrm{SM}-1$ basalts. The high ${ }^{87} \mathrm{Sr} /{ }^{86} \mathrm{Sr}$ values are thought to reflect seawater $\mathrm{Sr}$ in secondary phases, although all samples were strongly leached in $\mathrm{HCl}$ before analysis. ${ }^{206} \mathrm{~Pb} /{ }^{204} \mathrm{~Pb}$ ratios range from 18.53 to 18.80 , and show high ${ }^{207} \mathrm{~Pb} /{ }^{204} \mathrm{~Pb}$ and ${ }^{208} \mathrm{~Pb} /{ }^{204} \mathrm{~Pb}$ ratios relative to ${ }^{206} \mathrm{~Pb} /$ ${ }^{204} \mathrm{~Pb}$ ratios, typical of Indian Ocean mid-ocean ridge (MORB) and oceanic-island basalts (OIB). Isotopic compositions of Leg 115 basalts generally fall between fields for MORB and Réunion Island basalts, consistent with the conclusion drawn from geochronological studies that Deccan flood basalt volcanism, the Chagos-Laccadive Ridge, and the Mascarene Plateau are all products of the Réunion mantle plume. Isotopic compositions of magmas produced by this plume have varied systematically with time in the direction of less "depleted," less MORB-like isotopic signatures. This compositional change has been accompanied by a decrease in eruption rate. We interpret Deccan volcanism as the voluminous beginning of the plume. Reduced entrainment of asthenosphere following melting of the plume head resulted in less MORB-like isotope ratios in magmas and a decrease in eruptive activity with time.
\end{abstract}

\section{INTRODUCTION}

The idea that stationary mantle plumes are responsible for intraplate volcanos and volcanic chains, such as Yellowstone, Hawaii, the Societies, and others, and on-ridge emergent volcanos such as Iceland and the Azores (Morgan, 1971) is now well established. Plumes rising beneath the ocean basins leave a record of aseismic volcanic ridges or seamount chains such as the Hawaiian-Emperor chain, the Louisville Ridge, the IcelandFaeroe Ridge, and the Ninetyeast Ridge. Thus, these chains and ridges provide an opportunity to investigate temporal variations in mantle plumes and answer such questions as how stationary are these chains and ridges, how does eruptive volume vary with time, how does composition vary with time. One of the principal scientific objectives of Leg 115 was to test the hypothesis that the Mascarene Plateau and the Chagos-Laccadive Ridge were produced by the Réunion mantle plume. If this hypothesis were confirmed, geochronological and geochemical studies of basalts recovered from these features would allow us to assess the history of the plume and to address the above questions.

In this paper, we report the results of $\mathrm{Sr}, \mathrm{Nd}$, and $\mathrm{Pb}$ isotopic studies of basalts recovered by drilling during Ocean Drilling Program (ODP) Leg 115 (Fig. 1). The study had two principal objectives: (1) a geochemical evaluation of the relationship of the Mascarene Plateau, the Chagos-Laccadive Ridge, and Deccan flood basalt volcanism to Réunion Island, and hence a test of the hypothesis that all are products of the same mantle plume; and (2) an investigation of how the compositions of this plume and its associated magmas have varied with time.

Mantle plumes themselves cannot be sampled directly; only samples of magmas associated with plumes are available for study. During its lifetime, a plume may reach the surface in various tectonic environments (e.g., beneath continental lithosphere,

\footnotetext{
${ }^{1}$ Duncan, R. A., Backman, J., Peterson, L. C., et al., 1990. Proc. ODP, Sci. Results, 115: College Station, TX (Ocean Drilling Program).

2 Department of Geological Sciences, Cornell University, Ithaca, NY 14853 , U.S.A.

${ }^{3}$ College of Oceanography, Oregon State University, Corvallis, OR 97331, U.S.A.
}

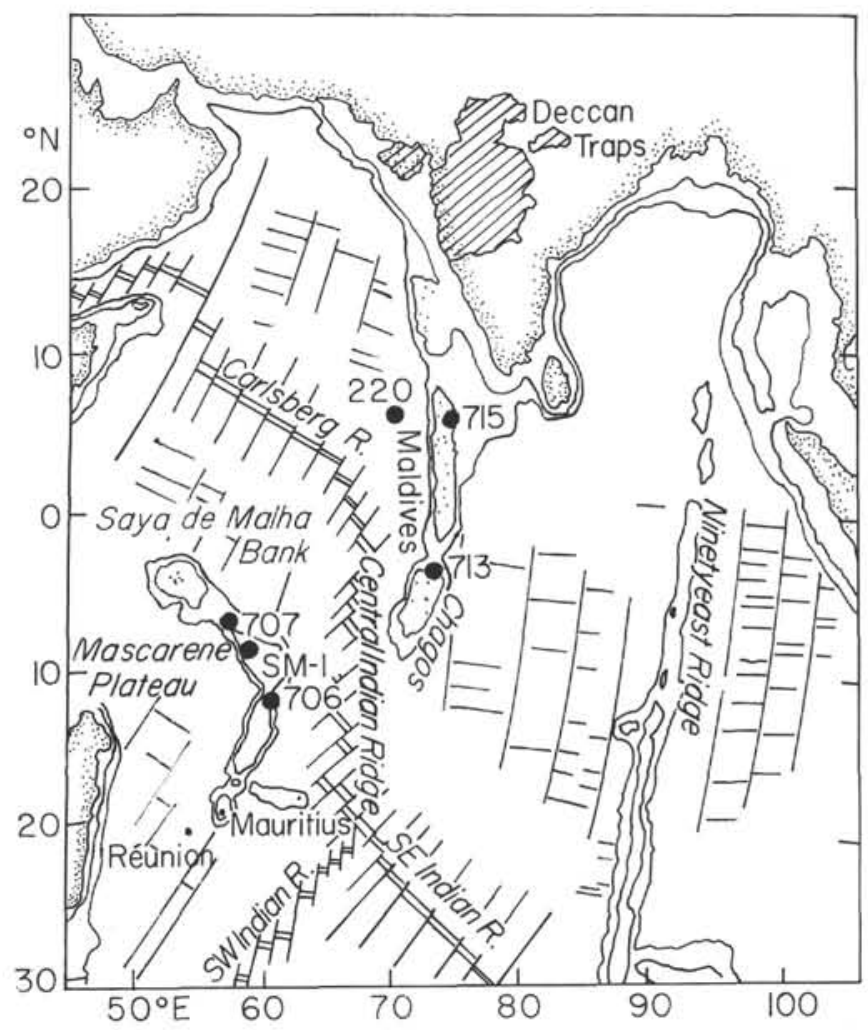

Figure 1. Map of the western Indian Ocean showing the location of the Deccan Traps, Leg 115 drill sites, Texaco drill site SM-1, DSDP Site 220, and the islands of Réunion and Mauritius.

spreading centers, and oceanic lithosphere). The composition of magmas associated with the plume may depend on the environment in which they are generated, even if the composition of the plume remains constant with time. For example, melts generated by a rising plume that encounters thick continental lithosphere might not reach the surface but may, instead, cause melt- 
ing of the lithosphere, or plume-generated melts might be contaminated by continental lithosphere and crust (e.g., Mahoney et al., 1983). At a spreading center, the geochemical signature of plume-derived melts may be diluted by mixing with asthenosphere-derived melts (e.g., Schilling, 1985). Plumes may also cause melting of the oceanic lithosphere and the asthenosphere, which may mix with plume-derived melts (e.g., Chen and Frey, 1983). Over its lifetime, a plume may encounter several of these situations, depending on the nature of the lithosphere overlying it, and the composition of the magmas stimulated by the thermal regime of the plume may vary accordingly.

In addition to the changes of tectonic regime, the composition of the plume itself might vary with time. Several studies examining these variations have now been made. Lanphere et al. (1980) found that the mean ${ }^{87} \mathrm{Sr} /{ }^{86} \mathrm{Sr}$ of tholeiites erupted along the Hawaiian-Emperor chain remained rather constant for the last 40 m.y. (greater variability on the Hawaiian islands themselves may simply reflect better sampling) and increased systematically with time between 70 and $40 \mathrm{Ma}$. Cheng et al. (1987) and Hawkins et al. (1987) concluded that the Louisville hotspot has been rather homogeneous over the last 75 m.y.

Trace element geochemistry of samples from the Ninetyeast Ridge is uniform and similar to that of oceanic-island basalt (OIB), except at Deep Sea Drilling Project (DSDP) Site 253, where basalts have affinities to mid-ocean ridge basalts (MORB) (Frey et al., 1977). The $\epsilon_{\mathrm{Nd}}$ values vary from 1.5 to 6.5 , with no apparent systematic relationship to age (Mahoney et al., 1983). Nevertheless, the available sampling of the Ninetyeast Ridge has been extremely sparse, so conclusions about temporal chemical variations are at best tenuous; analyses of samples returned by ODP Leg 121 should clarify the issue.

Temporal chemical variations in Iceland plume magmas were related by Schilling and Noe-Nygaard (1974) and Schilling et al. (1983) to changes in plume flux rather than to plume composition. Humphris and Thompson $(1982,1983)$ concluded that chemical variations in Walvis Ridge basalts mainly reflected a change in the location of the Tristan plume from on-ridge to off-ridge rather than to a change in the composition of the plume. Chemical variations within the volcanic pile, perhaps related to plume-induced melting of the lithosphere (e.g., Chen and Frey, 1983), may complicate the picture (Humphris and Thompson, 1984).

A particularly intriguing and important aspect of this study is the possible relationship of Deccan flood basalt volcanism to mantle plume activity. Duncan (1978) and Morgan (1981) proposed that the Deccan flood basalts were the initial product of the Réunion mantle plume. Other instances of continental flood basalt (CFB) volcanism also appear to be related to mantle plume activity. Duncan (1978), Morgan (1981), and Mahoney et al. (1983) speculated that the Rajmahal Traps of eastern India were related to the Kerguelen mantle plume, although Mahoney et al. (1983) felt that the plume was a source of heat rather than magma. Morgan (1981) suggested that the Parana and Etendeka CFB volcanism was caused by the Tristan da Cunha mantle plume, and that the Columbia River CFB volcanism was caused by the Yellowstone mantle plume. Although the relationship of the Yellowstone plume to the Columbia River CFB has been questioned (e.g., Carlson and Hart, 1988), there are a sufficient number of such examples to postulate that all CFB volcanism is caused by mantle plumes. Older examples of CFB volcanism may be difficult to relate to mantle plume activity only because other evidence of the plumes, such as island chains and aseismic ridges, have been subducted or otherwise destroyed.

The nature of the mantle source of CFB volcanism has been difficult to assess because of the effects of crustal assimilation. The extent of this assimilation has been a matter of considerable debate. Samples of CFB magma erupted through oceanic crust offer an opportunity to resolve this question because they would not have suffered crustal assimilation. In the case of the Deccan CFB volcanism, the opportunity is provided by basalts from Site 707, drilled in the Saya de Malha Bank, which plate reconstructions place originally at the western margin of the Indian continent, and which is not composed of continental crust.

The results of our study, together with geochronological studies of Leg 115 basalts and geochemical studies of Réunion and Deccan basalts, clearly indicate that the Réunion mantle plume was responsible for the Deccan continental flood basalt volcanism. We also find that $\epsilon_{\mathrm{Nd}}$ values of the erupted basalts associated with the plume have steadily declined with time; that is, the basalts show a progressively more "enriched" signature with time. Except for the effects of assimilation of crust and/or subcontinental lithosphere during Deccan volcanism, and decreasing entrainment of MORB asthenosphere, the isotopic compositions of Réunion mantle plume basalts appear to be unrelated to the tectonic environment in which they were erupted.

\section{ANALYTICAL METHODS}

Core samples were crushed in an iron plattner mortar, and chips of basalt were handpicked to remove as much altered material as possible and to exclude pieces exposed to the drill and saw. After selection, all further handling was carried out in an ultraclean environment. Samples were ultrasonically cleaned in distilled water and dried; $200 \mathrm{mg}$ of chips from each sample were weighed into a Teflon beaker. The samples were then leached for $1 \mathrm{hr}$ in hot, distilled $6 \mathrm{~N} \mathrm{HCl}$ to remove contamination introduced during drilling and handling and to remove $\mathrm{Sr}$ in remaining secondary phases. The samples were digested and $\mathrm{Pb}$ was extracted and purified with the $\mathrm{HBr}$ ion exchange technique described in White and Dupré (1986). The residue from the $\mathrm{Pb}$ extraction was converted to chloride, and $\mathrm{Sr}$ and $\mathrm{Nd}$ were extracted and purified with a BioRad AG50W-X12 and di-2-ethylhexyl orthophosphoric acid ion exchange technique (White and Patchett, 1984).

Lead was loaded on single Re filaments with silica gel and $\mathrm{H}_{3} \mathrm{PO}_{4}$ and analyzed in the VG Sector mass spectrometer at Cornell University. Ion beams of ${ }^{204} \mathrm{~Pb},{ }^{206} \mathrm{~Pb},{ }^{207} \mathrm{~Pb}$, and ${ }^{208} \mathrm{~Pb}$ were simultaneously collected in four Faraday cups, and isotope ratios were calculated after correction for differences in amplifier gain. An individual analysis consisted of $80-100$ integrations of $8 \mathrm{~s}$ each, with base lines measured between blocks of 10 integrations. The ${ }^{208} \mathrm{~Pb}$ ion beams were typically $1-4 \times 10^{-11}$ amps. To minimize sample-to-sample variations in mass fractionation during the analysis, all analyses were made at a filament temperature of $1350^{\circ} \mathrm{C}$. Lead isotope ratios were corrected for fractionation by applying a $1.1 \mathrm{~N}^{\circ} /$ amu correction. The correction factor was determined by repetitive analysis of NBS SRM981 , assuming values for this standard of ${ }^{206} \mathrm{~Pb} /{ }^{204} \mathrm{~Pb}=16.937$, ${ }^{207} \mathrm{~Pb} /{ }^{204} \mathrm{~Pb}=15.493$, and ${ }^{208} \mathrm{~Pb} /{ }^{204} \mathrm{~Pb}=36.705$. The $2 \sigma$ analytical uncertainty, based on the reproducibility of the NBS-981 standard, is \pm 0.012 for ${ }^{206} \mathrm{~Pb} /{ }^{204} \mathrm{~Pb}, \pm 0.013$ for ${ }^{207} \mathrm{~Pb} /{ }^{204} \mathrm{~Pb}$, and \pm 0.041 for ${ }^{208} \mathrm{~Pb} /{ }^{204} \mathrm{~Pb}$.

Strontium was loaded on single W filaments with $\mathrm{TaCl}_{5}-\mathrm{HF}$ activator and analyzed with a dynamic triple collector technique. Ratios were corrected for mass fractionation assuming that ${ }^{86} \mathrm{Sr} /{ }^{88} \mathrm{Sr}=0.11940$. An ion beam intensity of ${ }^{88} \mathrm{Sr}$ was maintained near $3 \times 10^{-11}$ amp during the analysis. The mean ${ }^{87} \mathrm{Sr} /{ }^{86} \mathrm{Sr}$ ratio of 58 analyses of the E\&A Sr isotopic standard was 0.708020 . Based on the reproducibility of this standard, the $2 \sigma$ analytical uncertainty is estimated at \pm 0.000035 .

Neodymium was loaded with a small amount of $\mathrm{H}_{3} \mathrm{PO}_{4}$ on triple filaments consisting of Re centers and Ta sides. Analysis was performed with a dynamic quintuple collector technique that allowed measurement of the ${ }^{143} \mathrm{Nd} /{ }^{144} \mathrm{Nd}$ ratio as a monitor of data quality. Ratios were corrected for mass fractionation, 
assuming ${ }^{146} \mathrm{Nd} /{ }^{144} \mathrm{Nd}=0.72190$. An ion beam intensity of ${ }^{144} \mathrm{Nd}$ was maintained near $1 \times 10^{-11} \mathrm{amp}$. The mean ${ }^{143} \mathrm{Nd}$ / ${ }^{144} \mathrm{Nd}$ and ${ }^{145} \mathrm{Nd} /{ }^{144} \mathrm{Nd}$ ratios of 45 analyses of the La Jolla isotopic standard were 0.511840 and 0.348401 , respectively. The ${ }^{145} \mathrm{Nd} /{ }^{144} \mathrm{Nd}$ ratios of samples always agreed with this value within analytical uncertainty. Based on the reproducibility of this standard, the $2 \sigma$ analytical uncertainty of the ${ }^{143} \mathrm{Nd} /{ }^{144} \mathrm{Nd}$ ratios is estimated at \pm 0.000016 .

\section{RESULTS}

Results are reported in Table 1. Strontium and neodymium isotope ratios are plotted in Figure 2. Leg 115 basalts are intermediate in isotopic composition between Indian Ocean MORB (particularly those from the Carlsberg and Central Indian ridges) and Réunion basalts, though there is some tendency for them to have somewhat higher ${ }^{87} \mathrm{Sr} /{ }^{86} \mathrm{Sr}$ ratios for a given value of $\epsilon_{\mathrm{Nd}}$ than Indian Ocean MORB. This may reflect incomplete removal of seawater alteration products during our leaching procedure. The SM-1 basalts have significantly higher ${ }^{87} \mathrm{Sr} /{ }^{86} \mathrm{Sr}$ ratios for a given $\epsilon_{\mathrm{Nd}}$ than do the Leg 115 basalts. We attribute this to seawater alteration. These samples were significantly more altered than the Leg 115 basalts and had abundant blue-green celadonite. Despite careful handpicking and leaching, alteration products apparently were not completely removed. Leg 115 basalts have $\epsilon_{\mathrm{Nd}}$ values comparable with the least contaminated Deccan basalts, namely the Ambenali Formation from the Western Ghats region of India, though they generally have lower ${ }^{87} \mathrm{Sr} /{ }^{86} \mathrm{Sr}$ than Ambenali basalts.

Figure 3 shows $\mathrm{Pb}$ isotope ratios of Leg 115 basalts. The Leg 115 basalts exhibit the high ${ }^{208} \mathrm{~Pb} /{ }^{204} \mathrm{~Pb}$ ratios relative to ${ }^{206} \mathrm{~Pb} /$ ${ }^{204} \mathrm{~Pb}$ ratios that are characteristic of Indian Ocean MORB and OIB. As is the case for ${ }^{87} \mathrm{Sr} /{ }^{86} \mathrm{Sr}$ and ${ }^{143} \mathrm{Nd} /{ }^{144} \mathrm{Nd}$ ratios, Leg 115 basalts appear to have $\mathrm{Pb}$ isotopic compositions intermediate between Indian Ocean MORB and Réunion basalts. Unlike ${ }^{87} \mathrm{Sr} /{ }^{86} \mathrm{Sr}$ and ${ }^{143} \mathrm{Nd} /{ }^{144} \mathrm{Nd}$, the $\mathrm{Pb}$ isotopic composition of $\mathrm{Leg}$ 115 basalts actually overlaps the Réunion field, though only barely. Interestingly, basalts from the youngest site (706) and Texaco drill site $\mathrm{SM}-1$ have $\mathrm{Pb}$ isotopic compositions most similar to those of Réunion basalts. Basalts from the remaining sites are displaced toward the field of Indian Ocean MORB. The ${ }^{206} \mathrm{~Pb} /{ }^{204} \mathrm{~Pb}$ ratios of Deccan basalts show an extremely wide range, which is probably a result of the assimilation of crust and old lithospheric mantle (Lightfoot and Hawkesworth, 1988). In general, they have higher ${ }^{208} \mathrm{~Pb} /{ }^{204} \mathrm{~Pb}$ ratios for a given ${ }^{206} \mathrm{~Pb} /{ }^{204} \mathrm{~Pb}$ ratio than do the Leg 115 basalts or Indian MORB, which may also be a result of crustal assimilation. Basalts from the Am- benali Formation, which appear from Nd isotope ratios to be the least contaminated of the Deccan basalts, have somewhat lower ${ }^{208} \mathrm{~Pb} /{ }^{204} \mathrm{~Pb}$ ratios.

Figure 4 is a plot of $\epsilon_{\mathrm{Nd}}$ vs. ${ }^{206} \mathrm{~Pb} /{ }^{204} \mathrm{~Pb}$. Leg 115 basalt compositions lie mainly within the Indian MORB field but show some displacement toward the Réunion field. With the exception of Sample 115-707C-26R-1, 11-15 cm, they form an almost linear trend extending toward the Réunion field. Deccan lavas show considerable scatter on this plot, but basalts from the Ambenali Formation have $\mathrm{Pb}$ isotope compositions that overlap those of MORB, consistent with the view that they are the least contaminated of the Deccan basalts (Lightfoot and Hawkesworth, 1988). In terms of $\mathrm{Nd}$ and $\mathrm{Pb}$ isotopic composition, the Leg 115 basalts can be described as being intermediate in composition between Indian MORB and Réunion basalts, but they can be almost equally described as being intermediate in composition between the least contaminated Deccan and Réunion basalts.

\section{Temporal Variations in Réunion Mantle Plume Magmas}

Duncan and Hargraves (this volume) have shown that the ages of Leg 115 basalts become progressively older from south to north and, hence, fit the model of a persistent, fixed mantle hotspot in the vicinity of Réunion Island. Deccan flood basalt volcanism, as well as the Chagos-Laccadive Ridge and Mascarene Plateau were sequentially formed over the Réunion mantle plume. That the isotopic compositions of Leg 115 and Réunion Island basalts form a continuum supports this idea. We think that the geochronological and geochemical evidence establishes this conclusion sufficiently well to adopt it as a working hypothesis and to explore it further. As we will show below, the isotopic compositions of basalts from Deccan, the Chagos-Laccadive Ridge, the Mascarene Plateau, Mauritius, and Réunion vary systematically with time, providing additional evidence that all are products of a single mantle plume.

Although the geochronological evidence indicates that the Mascarene Plateau, the Chagos-Laccadive Ridge, the Deccan flood basalts, Mauritius, and Réunion are all products of the same mantle plume, $\mathrm{Sr}, \mathrm{Nd}$, and $\mathrm{Pb}$ isotope ratios of Leg 115 basalts can be distinguished from those of Réunion and Deccan basalts, an observation that requires explanation. (Rodrigues Island may also be related to the Réunion mantle plume, but the nature of this relationship, if any, remains unclear.) Figure 5A shows the temporal variation in $\epsilon_{\mathrm{Nd}}$ of basalts associated with the Réunion mantle plume. Although at any given location significant variation occurs, there is a clear trend toward lower $\epsilon_{\mathrm{Nd}}$ through time. Neodymium isotope ratios of basalts from Mau-

Table 1. Isotope ratios in Leg 115 and Texaco drill site SM-1 basalts.

\begin{tabular}{lllllll}
\hline \multicolumn{1}{c}{$\begin{array}{c}\text { Core, section, } \\
\text { interval }(\mathrm{cm})\end{array}$} & ${ }^{87} \mathrm{Sr} /{ }^{86} \mathrm{Sr}$ & ${ }^{143} \mathrm{Nd} /{ }^{144} \mathrm{Nd}$ & ${ }^{\epsilon_{\mathrm{Nd}}}$ & ${ }^{206} \mathrm{~Pb} /{ }^{204} \mathrm{~Pb}$ & ${ }^{207} \mathrm{~Pb} /{ }^{204} \mathrm{~Pb}$ & ${ }^{208} \mathrm{~Pb} /{ }^{204} \mathrm{~Pb}$ \\
\hline $115-706 \mathrm{~B}-7 \mathrm{X}-\mathrm{CC}, 56-59$ & $0.70374 \pm 1$ & $0.512918 \pm 6$ & 5.46 & $18.799 \pm 0.003$ & $15.598 \pm 0.002$ & $38.934 \pm 0.006$ \\
$115-706 \mathrm{C}-5 \mathrm{R}-2,51-54$ & $0.70379 \pm 2$ & $0.512927 \pm 8$ & 5.64 & $18.778 \pm 0.001$ & $15.600 \pm 0.001$ & $38.938 \pm 0.003$ \\
$115-706 \mathrm{C}-9 \mathrm{R}-1,21-24$ & $0.70356 \pm 1$ & $0.512973 \pm 18$ & 6.54 & $18.671 \pm 0.003$ & $15.587 \pm 0.002$ & $38.817 \pm 0.007$ \\
$115-707 \mathrm{C}-23 \mathrm{R}-1,126-127$ & $0.70356 \pm 1$ & & & $18.633 \pm 0.012$ & $15.578 \pm 0.012$ & $38.432 \pm 0.025$ \\
$115-707 \mathrm{C}-23 \mathrm{R}-1,24-25$ & $0.70343 \pm 1$ & $0.512988 \pm 13$ & 6.83 & $18.592 \pm 0.006$ & $15.567 \pm 0.005$ & $38.646 \pm 0.016$ \\
$115-707 \mathrm{C}-26 \mathrm{R}-1,11-15$ & $0.70340 \pm 1$ & $0.513016 \pm 18$ & 7.37 & $18.779 \pm 0.003$ & $15.583 \pm 0.003$ & $38.709 \pm 0.007$ \\
$115-707 \mathrm{C}-27 \mathrm{R}-6,12-13$ & $0.70340 \pm 1$ & $0.513013 \pm 10$ & 7.32 & & & \\
$115-713 \mathrm{~A}-13 \mathrm{R}-1,22-27$ & $0.70368 \pm 1$ & $0.512974 \pm 6$ & 6.55 & & & \\
$115-713 \mathrm{~A}-19 \mathrm{R}-2,2-4$ & $0.70383 \pm 1$ & $0.512965 \pm 12$ & 6.38 & $18.620 \pm 0.003$ & $15.565 \pm 0.003$ & $38.640 \pm 0.007$ \\
$115-713 \mathrm{~A}-21 \mathrm{R}-1,2-5$ & $0.70376 \pm 1$ & $0.512975 \pm 10$ & 6.57 & $18.596 \pm 0.002$ & $15.572 \pm 0.003$ & $38.649 \pm 0.007$ \\
$115-715 \mathrm{~A}-26 \mathrm{R}-1,57-60$ & $0.70351 \pm 1$ & $0.512988 \pm 24$ & 6.83 & $18.534 \pm 0.002$ & $15.547 \pm 0.002$ & $38.552 \pm 0.006$ \\
$115-715 \mathrm{~A}-29 \mathrm{R}-1,5-8$ & $0.70330 \pm 1$ & & & $18.457 \pm 0.006$ & $15.539 \pm 0.006$ & $38.223 \pm 0.012$ \\
$115-715 \mathrm{~A}-30 \mathrm{R}-5,132-135$ & $0.70357 \pm 1$ & $0.512989 \pm 6$ & 6.85 & & & \\
SM-1 10190 & $0.70436 \pm 1$ & $0.512935 \pm 6$ & 5.79 & $18.766 \pm 0.005$ & $15.594 \pm 0.004$ & $38.792 \pm 0.010$ \\
SM-1 10490 & $0.70439 \pm 1$ & & & $18.781 \pm 0.006$ & $15.592 \pm 0.005$ & $38.810 \pm 0.013$ \\
SM-1 10610 & $0.70435 \pm 1$ & $0.512936 \pm 6$ & 5.81 & $18.732 \pm 0.002$ & $15.577 \pm 0.002$ & $38.775 \pm 0.005$ \\
& & & & & &
\end{tabular}

Notes: $\epsilon_{\mathrm{Nd}}$ is the fractional deviation, in units of parts per 10,000 , from the present-day chondritic ratio, which is taken as ${ }^{143} \mathrm{Nd} /{ }^{144} \mathrm{Nd}=0.512638$. 


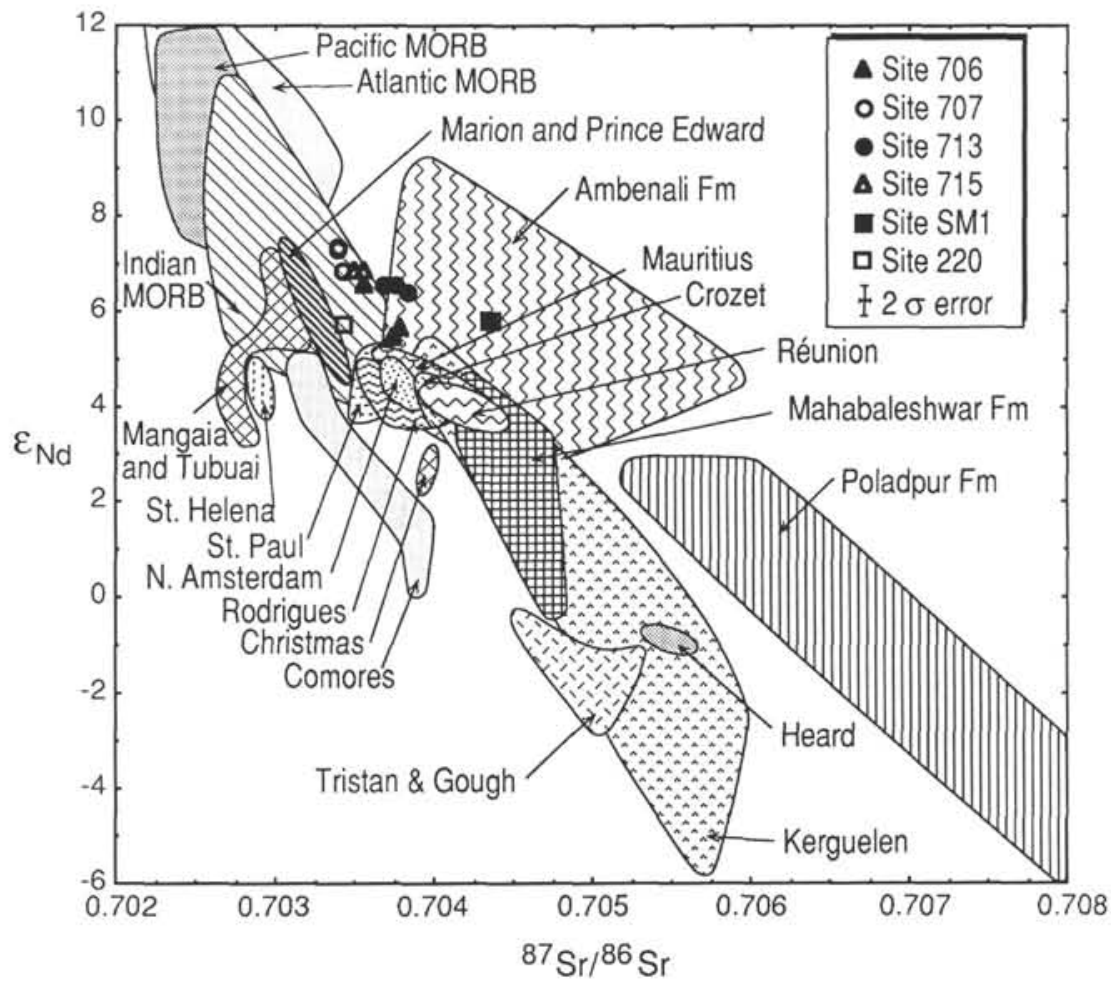

Figure 2. Sr and Nd isotopic variations in Leg 115 and Texaco drill site SM-1 basalts. Typical analytical uncertainty is shown in the legend. Shown for comparison are Site 220 (from Mahoney et al., 1989); fields for MORB (data from White et al., 1987, and references therein); Réunion (Fisk et al., 1988; W. M. White and B. Dupré, unpubl. data, 1984); Rodrigues (data from Baxter et al., 1985); Mauritius (data from Mahoney et al., 1989); the Ambenali, Mahabaleshwar, and Poladpur formations of the Deccan flood basalts from southwestern India (data from Mahoney et al., 1982; Lightfoot, 1985; Lightfoot and Hawkesworth, 1988); and several other islands from the Indian and South Atlantic oceans (White and Hofmann, 1982; Dupré and Allègre, 1983; Hart, 1988; Palacz and Saunders, 1986; W. M. White and B. Dupré, unpubl. data, 1984).

ritius (Mahoney et al., 1989) fit the pattern of temporal variations well. A regression line drawn through the data indicates an almost linear decrease in $\epsilon_{\mathrm{Nd}}$ from $65 \mathrm{Ma}$ to the present. The correlation between age and $\epsilon_{\mathrm{Nd}}$ is significant above the $99.5 \%$ level ( $r=0.916, n=23$; the correlation was performed after averaging the data from each of the two volcanos on Réunion). A nonlinear change, with a more rapid decrease in $\epsilon_{\mathrm{Nd}}$ since about $35 \mathrm{Ma}$, is a possible alternative interpretation and is illustrated by the shading in Figure 5A. However, this interpretation depends heavily on a single analysis from Site 706 with high $\epsilon_{\mathrm{Nd}}$.

Strontium and lead isotope ratios also exhibit temporal variations, as may be seen in Figures 5B and 6, although they are less systematic than temporal $\epsilon_{\mathrm{Nd}}$ variations. Strontium isotope ratios show somewhat more scatter at a given age, particularly for the islands of Réunion, Rodrigues, and Mauritius, and Site 715 has a lower mean ${ }^{87} \mathrm{Sr} /{ }^{86} \mathrm{Sr}$ ratio than does Site 707 . How much of the variation in ${ }^{87} \mathrm{Sr} /{ }^{86} \mathrm{Sr}$ is caused by secondary alteration is unclear. Nevertheless, a trend of increasing ${ }^{87} \mathrm{Sr} /{ }^{86} \mathrm{Sr}$ through time is apparent. The correlation between ${ }^{87} \mathrm{Sr} /{ }^{86} \mathrm{Sr}$ and time and ${ }^{206} \mathrm{~Pb} /{ }^{204} \mathrm{~Pb}$ and time, although not as strong as that of $\epsilon_{\mathrm{Nd}}$, are both significant at the $99.5 \%$ level $(r=-0.666, n=$ 25 , and $r=-0.719, n=15$, respectively).

The ${ }^{206} \mathrm{~Pb} /{ }^{204} \mathrm{~Pb}$ ratios show a systematic increase from about $58 \mathrm{Ma}$ (the age of Site 715 basalts) to the present (Fig. 6). However, ${ }^{206} \mathrm{~Pb} /{ }^{204} \mathrm{~Pb}$ ratios of Site 707 basalts are higher than those of Site 715. Lead isotope ratios in Deccan basalts exhibit an extreme range, most of which is undoubtedly a result of crustal as- similation as well as possible contributions from subcontinental lithosphere. Basalts from the Ambenali Formation have $\mathrm{Pb}$ isotope compositions most like oceanic basalts (MORB and OIB). This is consistent with their high Nd isotope ratios, which imply that they are the least contaminated of the Deccan basalts. These data are shown in Figure 6. Ambenali basalts have ${ }^{206} \mathrm{~Pb} /$ ${ }^{204} \mathrm{~Pb}$ ratios that overlap those of basalts from Site 713. The maximum ${ }^{206} \mathrm{~Pb} /{ }^{204} \mathrm{~Pb}$ ratios in Ambenali basalts plot close to an extension of the temporal trend observed in Leg 115 basalts, if those from Site 707 are excluded. Although the temporal trend for $\mathrm{Pb}$ isotope ratios is less well defined than those for $\mathrm{Sr}$ and $\mathrm{Nd}$ isotopes, the three isotope systems, when considered together, clearly indicate that the sources of these magmas became less "depleted" with time.

Figures 5 and 6 indicate that the differences in isotopic composition between the basalts of Réunion, Mauritius, the Mascarene Plateau, and the Chagos-Laccadive Ridge are a result of temporal variations in the magma sources. Similarly, some of the differences in isotopic composition between Réunion and Deccan basalts also appear to be caused by temporal variations in source geochemistry; most of the differences between Deccan and Réunion basalts simply reflect continental crustal and lithospheric contributions to Deccan magmas.

Magma production associated with the Réunion mantle plume has also varied with time. The Deccan flood basalts now outcrop over $5 \times 10^{5} \mathrm{~km}^{2}$, and may initially have had an area in excess of $1.5 \times 10^{6} \mathrm{~km}^{2}$ (e.g., Courtillot et al., 1986), with present 

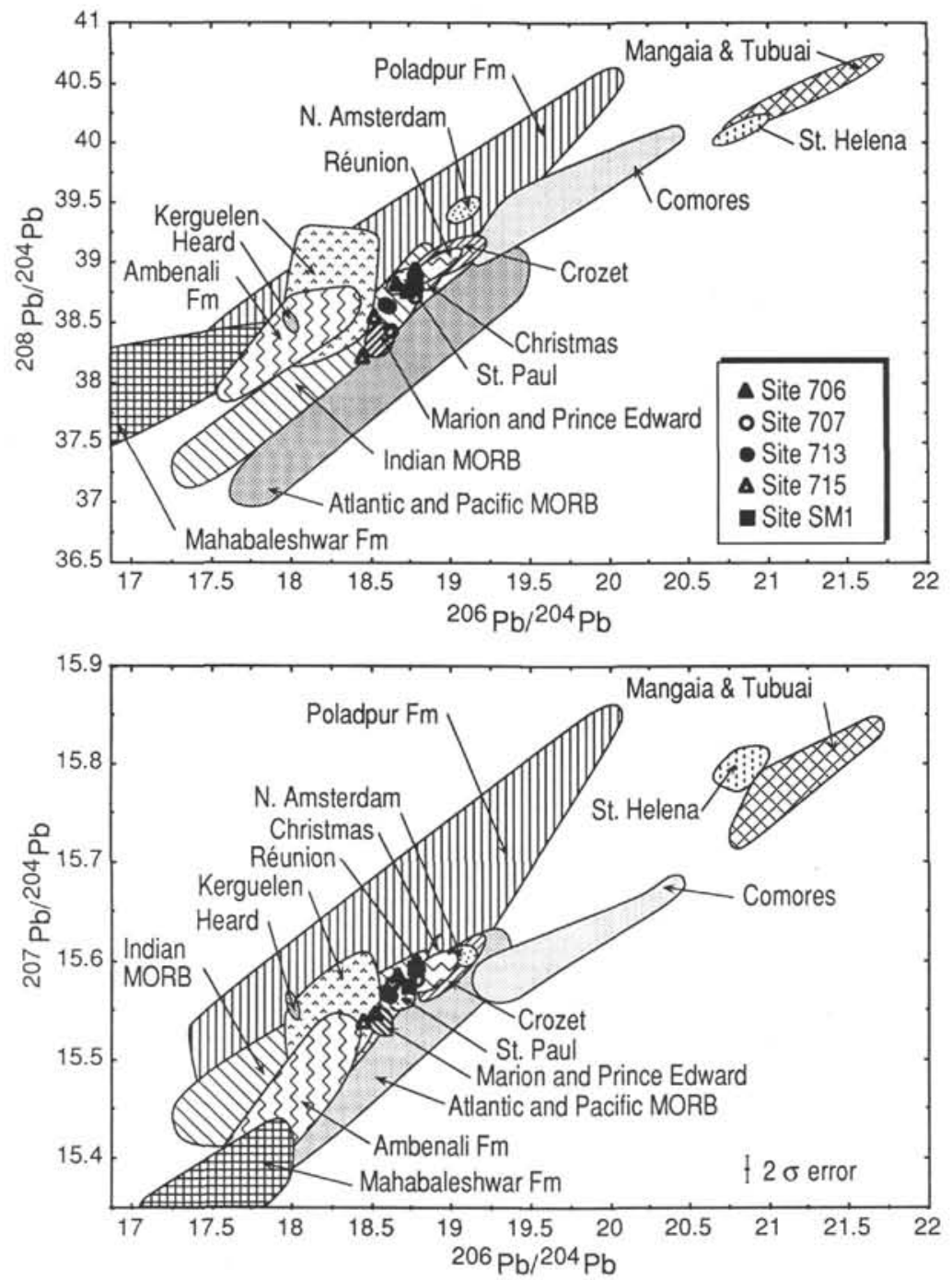

Figure 3. $\mathrm{Pb}$ isotope ratios in Leg 115 and Texaco drill site SM-1 basalts. Note that on the ${ }^{208} \mathrm{~Pb} /{ }^{204} \mathrm{~Pb}-{ }^{206} \mathrm{~Pb} /{ }^{204} \mathrm{~Pb}$ plot, analytical uncertainty is smaller than the size of the plotting symbol. Shown for comparison are data from Réunion basalts, MORB, islands of the Indian and South Atlantic oceans, and the Ambenali, Mahabaleshwar, and Poladpur formations of the Deccan flood basalts from southwestern India. Data sources are the same as in Figure 2.

stratigraphic thicknesses that vary from 1700 to $200 \mathrm{~m}$ or less (e.g., Mahoney, 1988). The total original volume of about 1.5 $\times 10^{6} \mathrm{~km}^{3}$ was erupted in $1 \mathrm{~m} . \mathrm{y}$. or less (Duncan and Pyle, 1988; Courtillot et al., 1988), yielding an eruption rate of $>1$ $\mathrm{km}^{3} / \mathrm{yr}$. The volcanic cone of Réunion Island has a volume above the $4000-\mathrm{m}$ isobath of roughly $7.5 \times 10^{4} \mathrm{~km}^{3}$. Subareal volcanic activity at Réunion has spanned the last 2 m.y. (McDougall, 1971), indicating an eruption rate of $0.04 \mathrm{~km}^{3} / \mathrm{yr}$. This is somewhat higher than the estimate by Bachelery et al. (1982) of the current Réunion magma production rate (i.e., $0.01 \mathrm{~km}^{3}$ ) yr). Eruption rates for intervening locations along the hotspot track are more problematic, given the uncertainties in the proportions of volcanic to carbonate platform making up the ridges, and the magnitude of erosion and subsidence.

Although these estimates are crude, it is clear that magmatic activity associated with the Réunion mantle plume has declined between Deccan times and the present, perhaps by a factor of $25-100$. It is tempting to relate this in some manner to the systematic variation in isotope geochemistry of the magmas, which has shifted toward less depleted, less MORB-like compositions. Magma output from the hotspot depends on both the total plume flux and the heat available for melting. It is widely thought that plumes originate in a thermal boundary layer, probably in the deep mantle (e.g., Courtillot and Besse, 1987; Sleep et al., 1988; Richards et al., 1989). Plumes presumably begin as instabilities in such a layer and develop large-volume, diapiric heads fed by narrow conduits as they rise buoyantly through the mantle (Whitehead and Luther, 1975; Griffiths, 1986). Once a plume forms and begins to rise, thermal diffusion should warm the surrounding mantle material, lowering its viscosity sufficiently to cause large-scale entrainment and mixing (Griffiths, 1986). Deccan volcanism could mark the voluminous beginning of the plume (or at least the time at which it reached the surface), as there is no evidence for the plume before Deccan time. If such plume models are correct, we would expect to see evidence for early mixing of lower mantle and entrained MORB-like, upper mantle material, which is inferred from the compositions of least contaminated Deccan basalts. Reduced entrainment of up- 


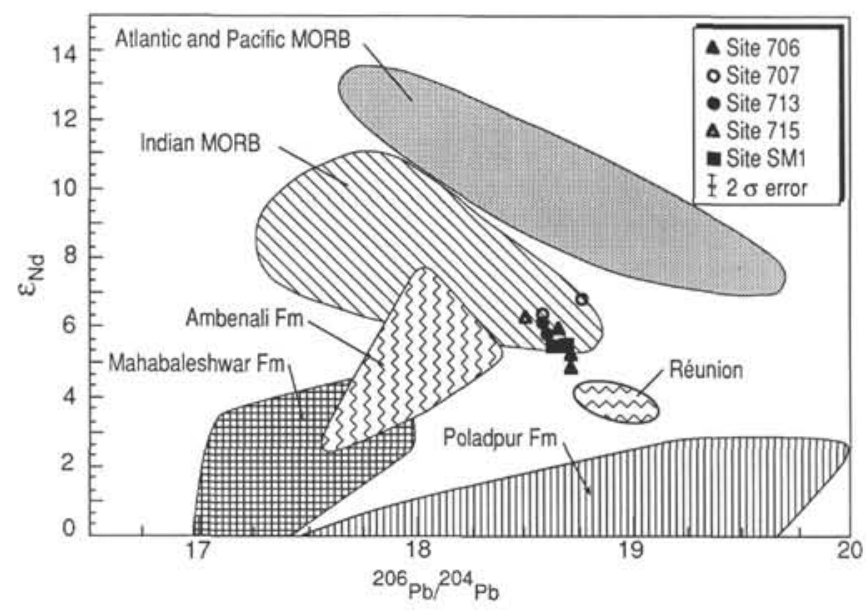

Figure 4. Variation of $\epsilon_{\mathrm{Nd}}$ vs. ${ }^{206} \mathrm{~Pb} /{ }^{204} \mathrm{~Pb}$ for Leg 115. Shown for comparison are data from Réunion, MORB, and the Ambenali, Mahabaleshwar, and Poladpur formations of the Deccan flood basalts from southwestern India. Data sources are the same as in Figure 2.

per mantle material after melting of the plume head is seen in a decreasing MORB component in magmas with time (Fig. 5). The apparent decrease in eruptive activity with time is also consistent with decreasing plume flux.

\section{Cause of Temporal Variation of the Réunion Mantle Plume}

It is clear from the preceding discussion that there are temporal variations in the composition of magmas produced by the Réunion mantle plume. We consider three possible causes for this variation: (1) the plate tectonic environment in which the magmas erupted, (2) the effects of variable degrees of partial melting of a plume that is heterogeneous on a small scale, and (3) variations in the composition of the plume itself.

The plate tectonic environment clearly influenced the composition of magmas erupted during the Deccan flood basalt event. Deccan lavas have ${ }^{87} \mathrm{Sr} /{ }^{86} \mathrm{Sr}$ ratios as high as 0.720 , and $\epsilon_{\mathrm{Nd}}$ as low as $<-16$, values which, along with such other observations as the presence of crustal xenoliths in some lavas, indicate pervasive contamination of magma by continental crust (e.g., Cox and Hawkesworth, 1985; Mahoney, 1988). Most recent studies have concluded that subcontinental lithosphere was also involved in the genesis of some Deccan lavas, either through partial melting of the lithosphere or through assimilation of the lithosphere by plume- or asthenosphere-derived melts (e.g., Lightfoot and Hawkesworth, 1988).

Following Deccan volcanism and the northward motion of India away from the Réunion plume, hotspot magmas would have been erupted in the newly formed Indian Ocean basin. In an oceanic setting, the most significant plate tectonic variable likely to have been of importance is the distance from a spreading center, which can be correlated with such other variables as the temperature of the surrounding asthenosphere and the lithosphere thickness that the magmas penetrated. Because the asthenosphere beneath spreading centers is partially molten and hotter than asthenosphere elsewhere, a plume, or plume-derived magmas, may mix more extensively with it. In this case, hotspot products might have more MORB-like isotopic compositions. In contrast, a thicker lithosphere at greater distances from a spreading center could provide greater opportunities for ascending plume-derived magmas to assimilate lithosphere. Most of the lithosphere will be MORB-like, but the upper crust will be enriched in alkali elements and ${ }^{87} \mathrm{Sr} /{ }^{86} \mathrm{Sr}$, having chemically exchanged with seawater. Hence, lithosphere assimilation could lead to more MORB-like isotopic compositions or to alkali and ${ }^{87} \mathrm{Sr} /{ }^{86} \mathrm{Sr}$ enrichments with increasing distance from the spreading center. (Lithospheric thickness might also control the depth at which plume magmas segregate, an issue we discuss separately below.) Worldwide, ocean-island magmas seem to be more MORB-like when the plume is near a spreading center (McBirney and Gass, 1967).

The distance from a spreading center, however, does not readily explain the temporal variation observed. Plate reconstructions suggest that the plume would have been located approximately near the nascent Carlsberg spreading center at the time of Site 707 volcanism, at approximately $64 \mathrm{Ma}$ (Duncan, this volume). Between that time and $34 \mathrm{Ma}$ (roughly Site 706 time), the plume lay beneath the Indian Plate (since there is no trace of the plume on the African Plate), although probably never far from the spreading center. At about the time of the eruption of Site 706 basalts, the spreading center crossed over the plume. Thus, since the time of Deccan volcanism, the plume would have been nearest a spreading center at the time of Sites 707 and 706. Since $34 \mathrm{Ma}$, the plume has been located beneath the African Plate at an increasing distance from the spreading center. Hence, if the temporal variations were related to distance to the spreading center in a simple manner, we would predict the following: (1) the isotopic composition of Réunion hotspot basalts should have been most MORB-like at the time of Site 706; (2) rather MORB-like isotopic compositions would occur at Site 707 , although the proximity to the Indian continent (and assimilation) may have been a more important effect; and (3) Sites 713 and 715 should have been less MORB-like than Site 706 . These predictions are not consistent with the observations, primarily because Site 706 basalts do not, on the whole, have particularly MORB-like isotopic compositions. Although the limited number of sites sampled and intrasite variability leave the exact nature of the temporal variation somewhat ambiguous, we conclude that the plate tectonic environment, or distance from a spreading center, has not been the dominant effect.

It is conceivable that if the plume were heterogeneous on a small scale, say $10-100 \mathrm{~m}$, variations in degree of melting might produce isotopic variations in the magmas even though the plume remains homogeneous on a large scale. This could occur if there are small-scale regions, perhaps veins or lenses, within the plume having more "enriched," or less "depleted," isotopic signatures and lower melting temperatures than other regions (Hanson, 1977; Batiza and Vanko, 1983; Zindler et al., 1984). This hypothesis would require that the degree of melting within the plume decrease over time and would be consistent with the apparent decrease in magmatic activity associated with the plume. A decrease in degree of melting through time implies a decrease in temperature. One might explain this by speculating that plume initiation in a thermal boundary layer would occur where temperatures are highest. Once it has formed, material at somewhat lower temperatures might be drawn into the plume more readily. Thus, a temporal decrease in temperature and the degree of melting might have a plausible fluid-dynamic cause.

Although a decreasing degree of melting is consistent with the decreasing magma production rate observed, it seems unlikely that the degree of melting has changed sufficiently to explain the magnitude of the drop in magma output, which we estimated above to be a factor of 25-100. The degree of melting involved in the production of basaltic magma is not well known, but a consensus exists that it does not exceed $25 \%-30 \%$. If we assume this maximum degree of melting for the Deccan, the de- 

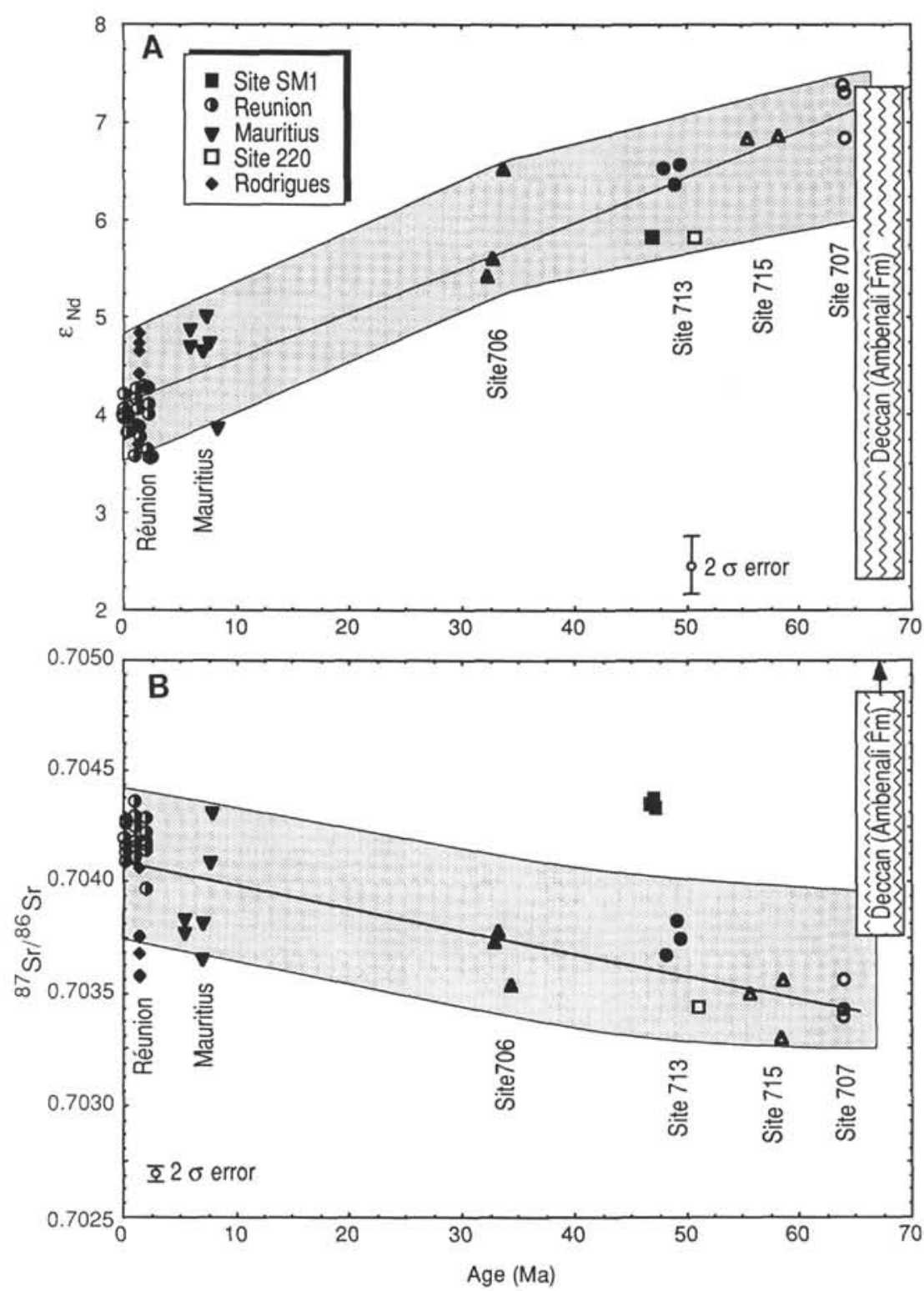

Figure 5. A. $\epsilon_{\mathrm{Nd}}$ as a function of eruption age for Réunion mantle plume magmas. The line through the data is a regression line. Shading shows the maximum variation. Data for Rodrigues is also included, although its relationship to the Réunion mantle plume is uncertain. Data sources are the same as in Figure 2. B. Variation of ${ }^{87} \mathrm{Sr} /{ }^{86} \mathrm{Sr}$ ratios with eruption ages for Réunion mantle plume magmas. The line through the data is a regression line, with data from Texaco drill site SM-1 excluded. High values in Texaco drill site SM-1 basalts are thought to reflect post-eruptive alteration. Data sources are the same as in Figure 2.

gree of melting would have to be $1 \%$ or less for Réunion. This is an implausibly small degree of melting in view of the generally hypersthene-normative nature of Réunion lavas.

The final possible cause of temporal isotopic variations of plume magmas is from changes in the geochemistry of the plume itself. This variation might reflect either changes in the composition of the material rising from the plume source in the thermal boundary layer, or mixing between this plume material and entrained asthenosphere. Geochemical variations in the plume material itself are certainly plausible, but this is a rather difficult hypothesis to test. Figures 2-6 show that the isotopic compositions of the magmas associated with the Réunion mantle plume have shifted progressively away from the MORB field with time. This would be consistent with decreasing dilution of the plume material by entrained asthenosphere. This possibility was discussed in an earlier section, and we concluded that decreasing entrainment of asthenosphere could potentially explain the apparent decrease in eruption rate. This possibility could be evaluated from a fluid-dynamic standpoint, but such an evaluation is beyond the scope of this paper.

We conclude, therefore, that the most plausible explanation for the temporal variation in isotope geochemistry of Réunion mantle plume magmas is the decreasing entrainment of asthenosphere by the rising plume. We reached this conclusion because it also explained the apparent decrease in eruptive activity associated with the plume, and because it has a plausible fluid-dynamic basis. Although we cannot rule out the possibility that the composition of the plume material itself or the degree of 


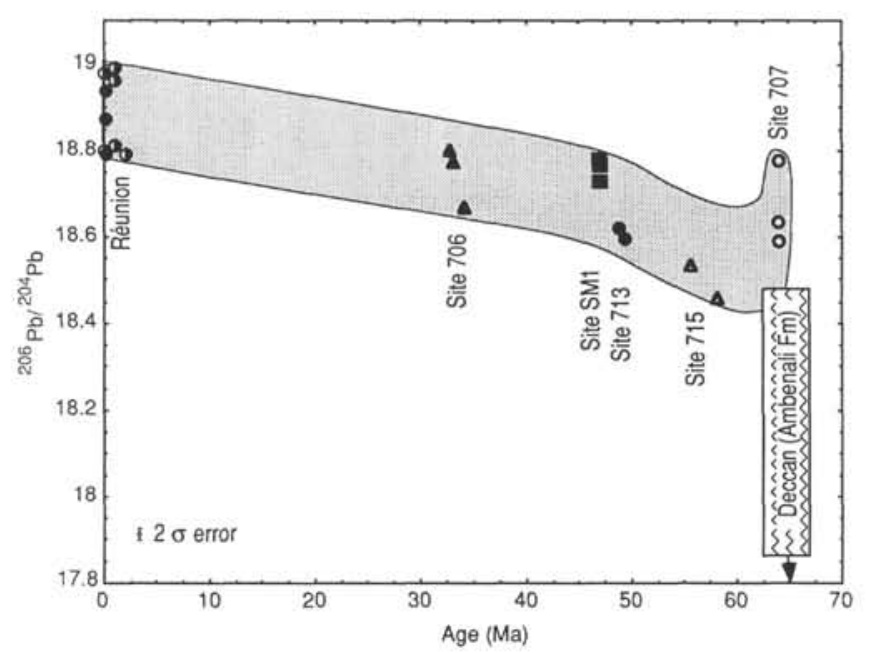

Figure 6. Variation of ${ }^{206} \mathrm{~Pb} /{ }^{204} \mathrm{~Pb}$ ratios with eruption ages for Réunion mantle plume magmas. Data sources are the same as in Figure 2.

melting has varied with time, these possibilities cannot explain the concomitant decrease in eruptive activity.

\section{Relationship of Leg 115 and Deccan Basalts}

Basalts from Site 707 were apparently erupted onto the oceanic crust shortly after the eruption of massive volumes of Deccan lavas through and onto the Indian continental crust. There is an apparent consensus, summarized by Mahoney (1988), among geochemists and petrologists who have studied the Deccan basalts that virtually all are pervasively, but variably, contaminated by continental crust, apparently largely granitic material (sensu lato) of Archean age. This contamination accounts for the high ${ }^{87} \mathrm{Sr} /{ }^{86} \mathrm{Sr}$, high ${ }^{208} \mathrm{~Pb} /{ }^{204} \mathrm{~Pb}$ and ${ }^{207} \mathrm{~Pb} /{ }^{204} \mathrm{~Pb}$, and low ${ }^{143} \mathrm{Nd} /{ }^{144} \mathrm{Nd}$ ratios of most Deccan lavas. There is also agreement that, in a few cases, Deccan magmas could have been contaminated by subcontinental lithospheric mantle rather than by continental crust. For example, Lightfoot and Hawkesworth (1988) attribute the low ${ }^{206} \mathrm{~Pb} /{ }^{204} \mathrm{~Pb}$ ratios in Mahabaleshwar and $\mathrm{Am}-$ benali magmas to a continental lithospheric component. Mahoney et al. (1982) also argued that at least two assimilates were required: an upper crustal "granitic" component, and a lower crustal "granulitic component" or an "incompatible-elementenriched mantle" component.

If the isotopic characteristics of Site 707 basalts are those of the uncontaminated mantle source of Deccan basalts, they present a rather unique opportunity to test hypotheses of Deccan magma genesis. Lightfoot and Hawkesworth (1988) attributed chemical variations in Mahabaleshwar and Ambenali lavas to mixing between T-type MORB (i.e., transitional between normal and plume-derived MORB) and continental lithosphere. Mahoney (1988) argued that the mantle source of Deccan magmas was a blend of present-day Réunion hotspot and Central Indian Ridge mantle, and that even the least contaminated Deccan magmas are slightly contaminated by continental crust or lithospheric mantle. These are precisely the conclusions we have reached regarding the composition of the Réunion mantle plume in Deccan time. The isotopic compositions of Site 707 basalts can be modeled as a blend of Réunion and Indian Ocean MORB sources.

All $\mathrm{Pb}$ isotope ratios reported thus far for Deccan lavas have higher ${ }^{208} \mathrm{~Pb} /{ }^{204} \mathrm{~Pb}$ ratios for a given value of ${ }^{206} \mathrm{~Pb} /{ }^{204} \mathrm{~Pb}$ than Réunion or Leg 115 lavas (Fig. 3), implying that all have been contaminated to at least a slight degree. And, although $\epsilon_{\mathrm{Nd}}$ values in the least contaminated Deccan lavas are similar to those in Site 707 lavas, $\mathrm{Sr}$ isotope ratios in the former are higher, again implying some contamination (this might also be explained by posteruptive contamination because all Deccan lavas are somewhat altered; Mahoney, 1988). Finally, the intermediate ${ }^{206} \mathrm{~Pb} /$ ${ }^{204} \mathrm{~Pb}$ ratios of Site 707 basalts relative to those of Deccan as a whole require at least two contaminants for the latter: one with high ${ }^{206} \mathrm{~Pb} /{ }^{204} \mathrm{~Pb}$ and one with low ${ }^{206} \mathrm{~Pb} /{ }^{204} \mathrm{~Pb}$. Our data do not provide any clear indication as to whether the low ${ }^{206} \mathrm{~Pb} / 204 \mathrm{~Pb}$ assimilate is subcontinental lithosphere or lower crust. Identification of the composition of the plume, however, should make it easier for future studies of Deccan volcanism to explain the contamination process and identify the contaminants.

\section{CONCLUSIONS}

The most important result of this study is the demonstration that Deccan flood basalt volcanism, the Chagos-Laccadive Ridge, the Mascarene Plateau, and Réunion Island are geochemically related and are all products of the same mantle plume. Although the suspicion that continental flood basalt volcanism is caused by mantle plumes has been around for some time, this and companion studies of Leg 115 basalts provide convincing evidence that this was indeed the case, at least for the Deccan event. We have shown that the isotopic ratios of magmas derived from the Réunion mantle plume have varied systematically with time toward less "depleted" signatures. This geochemical variation was accompanied by a decrease in magma output from the plume, although precisely how magma output varied and by how much is still somewhat unclear. After considering several alternatives, we conclude that the geochemical and magma output changes reflect a decrease in the entrainment of asthenosphere within upwelling plume material with time.

\section{ACKNOWLEDGMENTS}

We thank J. Mahoney and an anonymous reviewer for their constructive criticism of this manuscript.

\section{REFERENCES}

Bachelery, P., Blum, P. A., Cheminee, J. L., Chevallier, L., Gaulon, R., Girardin, N., Jaupart, C., Lalanne, F., Le Mouel, J. L., Reugg, J. C., and Vincent, P., 1982. Eruption at Le Piton de la Fournaise Volcano on 3 February 1981. Nature, 297:395-397.

Batiza, R., and Vanko, D., 1984. Petrology of young Pacific seamounts. J. Geophys. Res., 89:11,235-11,260.

Baxter, A. N., Upton, B.G.J., and White, W. M., 1985. Petrology and geochemistry of Rodrigues Island, Indian Ocean. Contrib. Mineral. Petrol., 89:90-101.

Carlson, R. W., and Hart, W. K., 1988. Flood basalt volcanism in the northwestern United States. In Macdougall, J. D. (Ed.), Continental Flood Basalts: Dordrecht (Kluwer Academic Publishers), 35-61.

Chen, C.-Y., and Frey, F. A., 1983. Origin of Hawaiian tholeiite and alkalic basalt. Nature, 302:785-789.

Cheng, Q., Park, K.-H., Macdougall, J. D., Zindler, A., Lugmair, G. W., Staudigel, H., Hawkins, J., and Lonsdale, P., 1987. Isotopic evidence for a hotspot origin of the Louisville Seamount chain. In Keating, B. H., Fryer, P., Batiza, B., and Boehlert, G. W. (Eds.), Seamounts, Islands, and Atolls. Am. Geophys. Union Monogr., 43: 283-296.

Courtillot, V., and Besse, J., 1987. Magnetic field reversals, polar wander, and core-mantle coupling. Science, 237:1140-1147.

Courtillot, V., Besse, J., Vandamme, D., Montigny, R., Jaeger, J.-J., and Capetta, H., 1986. Deccan flood basalts at the Cretaceous/Tertiary boundary? Earth Planet. Sci. Lett., 80:361-374.

Courtillot, V., Féraud, G., Maluski, H., Vandamme, D., Moreau, M. G., and Besse, J., 1988. Deccan flood basalts and the Cretaceous/Tertiary boundary. Nature, 333:843-846.

Cox, K. G., and Hawkesworth, C. J., 1985. Geochemical stratigraphy of the Deccan Traps at Mahabaleshwar, Western Ghats, India, with implications for open system magmatic processes. J. Petrol., 26:355377. 
Duncan, R. A., 1978. Geochronology of basalts from the Ninetyeast Ridge and continental dispersion in the eastern Indian Ocean. $J$. Volcanol. Geotherm. Res., 4:283-305.

Duncan, R. A., and Pyle, D. G., 1988. Rapid eruption of the Deccan flood basalts at the Cretaceous/Tertiary boundary. Nature, 333:841843.

Dupré, B., and Allègre, C. J., 1983. Pb-Sr isotope variation in Indian Ocean basalts and mixing phenomena. Nature, 303:142-146.

Frey, F., Dickey, J. S., Thompson, G., and Bryan, W. B., 1977. Eastern Indian Ocean DSDP sites: correlations between petrography, geochemistry and tectonic setting. In Heirtzler, J. R., Bolli, H. M., Davies, T. A., Saunders, J. B., and Sclater, J. G. (Eds.), Indian Ocean Geology and Biostratigraphy: Washington (American Geophysical Union), 189-257.

Fisk, M. R., Upton, B.G.J., Ford, C. E., and White, W. M., 1988. Geochemical and experimental study of the genesis of magmas of Réunion Island, Indian Ocean. J. Geophys, Res., 93:4933-4950.

Griffiths, R. W., 1986. The differing effects of compositional and thermal buoyancies on the evolution of mantle diapirs. Phys. Earth Planet. Inter., 43:261-273.

Hanson, G. N., 1977. Geochemical evolution of the suboceanic mantle. J. Geol. Soc. (London), 134:235-253.

Hart, S. R., 1988. Heterogeneous mantle domains: signatures, genesis and mixing chronologies, Earth Planet. Sci. Lett., 90:273-296.

Hawkesworth, C. J., Mantovani, M. M., Taylor, P. N., and Palacz, Z., 1986. Evidence from the Parana of south Brazil for a continental contribution to Dupal basalts. Nature, 322:356-359.

Hawkins, J. W., Lonsdale, P., and Batiza, R., 1987. Petrologic evolution of the Louisville Seamount chain. In Keating, B. H., Fryer, P. Batiza, B., and Boehlert, G. W. (Eds.), Seamounts, Islands, and Atolls: Am. Geophys. Union Monogr., 43:235-254.

Humphris, S. E, and Thompson, G., 1982. A geochemical study of rocks from the Walvis Ridge, South Atlantic. Chem. Geol., 36:253274.

1983. Geochemistry of rare earth elements in basalts from the Walvis Ridge: implications for its origin and evolution. Earth Planet. Sci. Lett., 66:223-242.

1984. Petrology and geochemistry of rocks from the Angola Basin adjacent to the Walvis Ridge: Deep Sea Drilling Project Leg 75, Site 530. In Hay, W. W., Sibuet, J. C., et al., Init. Repts. DSDP, 75, Pt. 2: Washington (U.S. Govt. Printing Office), 1099-1105.

Lanphere, M. A., Dalrymple, G. B., and Clague, D. A., 1980. Rb-Sr systematics of basalts from the Hawaiian-Emperor volcanic chain. In Jackson, E. D., Koizumi, I., et al., Init. Repts. DSDP, 55: Washington (U.S. Govt. Printing Office), 695-706.

Lightfoot, P., 1985. Isotope and trace element geochemistry of the south Deccan lavas, India [Ph.D. dissert.]. Open Univ., Milton Keynes, United Kingdom.

Lightfoot, P., and Hawkesworth, C., 1988. Origin of Deccan Trap lavas: evidence from combined trace element and $\mathrm{Sr}-, \mathrm{Nd}-$ and $\mathrm{Pb}-$ studies. Earth Planet. Sci. Lett., 93:89-104.

McBirney, A. R., and Gass, I. G., 1967. Relations of oceanic volcanic rocks to mid-oceanic rises and heat flow. Earth Planet. Sci. Lett., 2: 265-276.

McDougall, I., 1971. The geochronology and evolution of the young volcanic island of Réunion, Indian Ocean. Geochim. Cosmochim. Acta, 35:261-288.
Mahoney, J. J., 1988. Deccan Traps. In Macdougall, J. D. (Ed.), Continental Flood Basalts: Dordrecht, The Netherlands (Kluwer Academic Publishers), 151-194.

Mahoney, J. J., Macdougall, J. D., Lugmair, G. W., and Gopalan, K., 1983. Kerguelen hotspot source for Rajmahal Traps and Ninetyeast Ridge? Nature, 303:385-389.

Mahoney, J. J., Macdougall, J. D., Lugmair, G. W., Murali, A. V., Sankar Das, M., and Gopalan, K., 1982. Origin of the Deccan Trap flows at Mahabaleshwar inferred from Nd and $\mathrm{Sr}$ isotopic and chemical evidence. Earth. Planet. Sci. Lett., 60:47-60.

Mahoney, J. J., Natland, J. H., White, W. M., Poreda, R., Bloomer, S. H., Fisher, R. L., and Baxter, A. N., 1989. Isotopic and geochemical provinces of the western Indian Ocean spreading centers. J. Geophys. Res., 94:4033-4052.

Morgan, W. J., 1971. Convection plumes in the lower mantle. Nature, 230:42-43.

1981. Hotspot tracks and the opening of the Atlantic and Indian oceans. In Emiliani, C. (Ed.), The Sea (Vol. 7): The Oceanic Lithosphere: New York (Wiley-Interscience), 443-487.

Palacz, Z., and Saunders, A. D., 1986. Coupled trace element and isotope enrichment in the Cook-Austral-Samoa islands, southwest Pacific. Earth Planet. Sci. Lett., 79:270-280.

Richards, M. A., Duncan, R. A., and Courtillot, V. E., 1989. Flood basalts and hotspot tracks: plume heads and tails. Science, 246:103107.

Schilling, J.-G., 1985. Upper mantle heterogeneities and dynamics. $\mathrm{Na}$ ture, 314:62-67.

Schilling, J.-G., Meyer, P. S., and Kingsley, R. H., 1983. Evolution of the Iceland hotspot. Nature, 296:313-320.

Schilling, J.-G., and Noe-Nygaard, A., 1974. Faeroe-Iceland plume: rare earth evidence. Earth Planet. Sci. Lett., 24:1-14.

Sleep, N. H., Richards, M. A., and Hager, B. H., 1988. Onset of mantle plumes in the presence of preexisting convection. J. Geophys. Res., 93:7672-7689.

White, W. M., and Dupré, B., 1986. Sediment subduction and magma genesis in the Lesser Antilles: isotopic and trace element constraints. J. Geophys. Res., 91:5927-5942.

White, W. M., and Hofmann, A. W., 1982. Sr and Nd isotope geochemistry of oceanic basalts and mantle evolution. Nature, 296:821825.

White, W. M., Hofmann, A. W., and Puchelt, H., 1987. Isotope geochemistry of Pacific MORB. J. Geophys. Res., 92:4881-4893.

White, W. M., and Patchett, P. J., 1984. Hf-Nd-Sr isotopes and incompatible-element abundances in island arcs: implications for magma genesis and crust-mantle evolution. Earth Planet. Sci. Lett., 67:167185.

Whitehead, J. A., and Luther, D. S., 1975. Dynamics of laboratory diapirs and plume models. J. Geophys. Res., 80:705-717.

Zindler, A., Staudigel, H., and Batiza, R., 1984. Isotope and trace element geochemistry of young Pacific seamounts: implications for the scale of upper mantle heterogeneity. Earth Planet. Sci. Lett., 70: 175-195.

Date of initial receipt: 1 June 1989

Date of acceptance: 13 November 1989

MS 115B-131 